\title{
Foreign Capital in Russia and Hong Kong: Postmortem of International Financial Crisis
}

\author{
Şaziye Gazioğlu, University of Aberdeen \\ Ülkem Başdaş, Middle East Technical University
}

\begin{abstract}
This paper studies the relation among real stock returns, real capital flows and real exchange rate starting from a theoretical model. The model predicts that the capital inflows affect the real exchange rate and stock returns. Besides, there is an asymmetry between the effect of capital inflows and outflows on real exchange rate causing a "Debt Trap". In this paper, we compare the evidence from Russia and Hong Kong. The empirical findings confirm the theoretical model for all three countries.
\end{abstract}

JEL Codes: E60, F30, G15

\section{Introduction}

International Financial Crisis has been studied to a great extend with the suggestion of various causes. The various theories used to explain the South East Asian, the Russian and the South American crises include the First and the Second generation Models and the Crisis of contagion effect argued that the First and the Second generation models (Eijffinger et al. 2002)do not explain the Asian crisis. However, none of these models formulated a macro model that would give a theoretical base to investigate International financial crisis.

Gazioğlu, Ş. and D. McCausland, (2002), developed the theoretical model and Gazioglu (2003, 2005, 2008) applied to the Turkish data to investigate the reversal effects of capital inflows on a developing country. After the 1980's, Turkey experienced an urgent and quick liberalization of markets where the restrictions on capital flows were eliminated. As Gazioğlu (2008) suggest, the nature of the Turkish economy makes it more volatile with respect to external shocks and more open to crises. Before the 2001 crisis, the South American experience indicated that Turkey might face similar problems in their banking sector (Gazioglu, 2005)).

The aim of this paper is to investigate the relationship between capital flows, banking sector, stock market returns and the crisis over Russia and Hong Kong. In this paper we empirically show that the increase in foreign share in financial services can be an indicator of overall economic performance for the countries which are heavily dependent on capital flows. Furthermore, our study shows that capital flows have a deeper effect on the exchange rate when the flow reversal causes an asymmetric impact. This may cause a debt trap for the home country. Our basic innovation is to have a theoretical base for our empirical work on Russia and Hong Kong. This is contrary to other studies, which are only empirical studies with just two variables, namely, exchange rate and stock market returns. Here we test the validity of the theoretical model for Russia and Hong Kong.

The paper is organized as follows; Section 2 introduces the model to test for the relation between capital flow, stock returns and the exchange rate; Section 3 analyzes the empirical evidence for Russia and Hong Kong; Section 4 concludes.

\section{Model}

\subsection{Theoretical Model}

We use the model developed by Gazioğlu $(2001,2002)$ and tested in Gazioglu $(2003,2005$, and 2008) for the Turkish data. The model solves the profit maximization problem of firm and 
time separable utility function and the maximization problem of a representative domestic consumer. The stock market constraint is given as:

$$
\boldsymbol{V}^{d} \dot{X}^{d} \equiv \boldsymbol{X}^{d} \dot{V}^{d}+X^{d} D^{d}
$$

$V^{d} X^{d}, X^{d} I_{\text {and }} X^{d} D^{d}$ denote the value of domestic firms owned by domestic individuals, domestic proportion of stock market valuation of these shares, and their proportion of dividends respectively.

Gazioğlu (2005) summarizes the equilibrium in economy as follows;

$$
\begin{aligned}
& \dot{X}-\boldsymbol{B H}=\boldsymbol{Y}-A-I+X^{d}\left(\dot{V}^{d} / V^{d}+D^{d} / V^{d}\right)+X^{f}\left(\dot{V}^{f} / V^{f}+D^{f} / V^{f}\right) \\
& +H(\boldsymbol{H}+\dot{E} / E)\left(1+R^{f}\right)
\end{aligned}
$$

Where the balance of payment equation can be given as;

$$
\dot{H}=\Pi-T+H(\mathbf{H}+\dot{E} / E)\left(1+R^{f}\right)
$$

Gazioğlu (2005) states that "net accumulation of assets can be accumulated by a trade surplus and capital gain from holding foreign money in terms of foreign goods", which is shown by equation (3). Then, equation (2) implies the equilibrium condition, where the right hand side is equal to net domestic income minus consumption and the left hand side is the net wealth accumulation. This equilibrium proves that a change in shares under foreign ownership in the domestic stock market is reflected to the domestic economy in terms of domestic debt. Therefore, a foreign shock can affect the domestic market via a change in shares under foreign ownership. The percent of shares under foreign ownership has a vital role in evaluating the sensitivity of the economy to foreign shocks. Greater percentage implies higher sensitivity and a more volatile economy.

Gazioğlu (2005) states the dynamics of the whole system as follows;

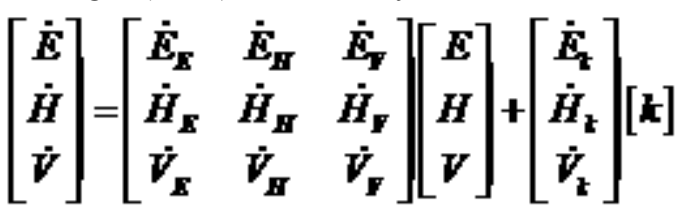

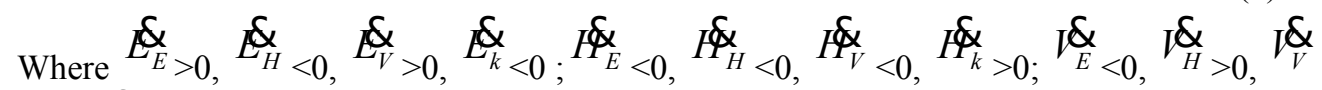

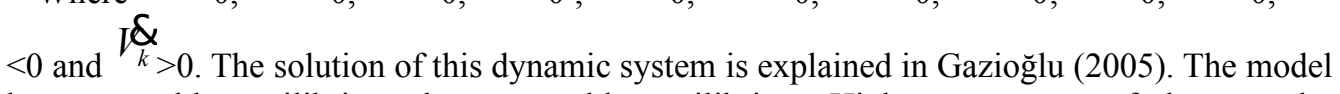
has two stable equilibria and one unstable equilibrium. Higher percentage of shares under foreign ownership causes an asymmetry between the capital inflows and outflows, which leads to the "Ponzi Game" position; the country borrows further to be able to repay debts (Gazioğlu, 2001, 2002, 2003).

\section{Empirical Evidence from Russia and Hong Kong:}

Gazioglu (2008) showed that for Turkey there is a link between the capital flows, real exchange rate and stock returns. Foreign share in the domestic economy is an important parameter affecting the whole economy. Besides, capital outflows have a greater impact than inflows. The case of Turkey can be investigated for other developing or under-developed countries, where there is a reliance on capital flows, or the capital flows captures a significant portion of the economy, or allow mobility of capital without prior construction of regulatory framework. To test our aim Russia and Hong Kong are chosen. In this paper, we test the validity of the model for Russia and Honk Kong. 


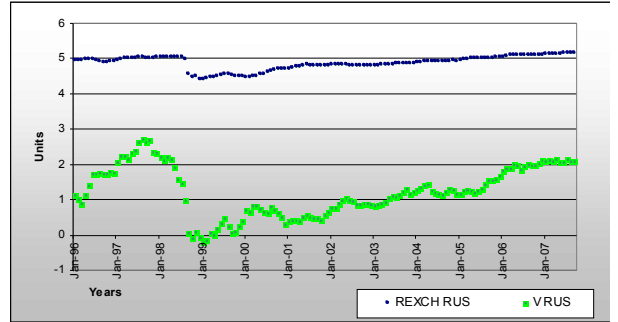

Figure 1 - The Real Effective Exchange Rate and Real Stock Returns in Log for Russia: 1996-2007

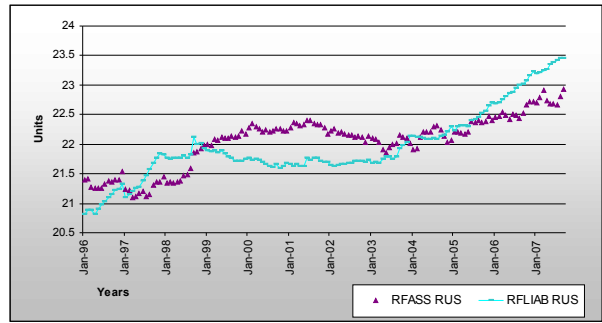

Figure 2 - Real Foreign/Liabilities in Log for Russia: 1996-2007

First we discuss the results for Russia. Both the Eigenvalue Test and the Trace Test verify that there is only one cointegrating vector. Estimation of vector via Johansen Estimation is calculated. One per cent increase in RFASS will increase REXCH by nearly 0.095 per cent implying that higher foreign assets will end up with appreciation of the domestic currency. The Stock returns index negatively affects the real effective exchange rate. The dummy variable has a negative sign meaning that, for the crisis period, domestic currency depreciation has been experienced.

For the capital outflow case, one per cent increase of RFLIAB causes a depreciation of 1.979 per cent. Compared to the inflow case (Model 1), capital outflow has a nearly 20 times higher effect on the exchange rate. Considering the coefficients of stock returns in Model 1 and Model 2, the coefficient is more significant for the outflow case. This indicates that capital inflows increase the stock returns and when an economic turbulence occurs it immediately moves out. The impact of capital inflow is higher than stock returns whereas the effect of capital outflow has nearly the same effect as stock returns. This proves the greater importance of capital flows on real exchange rate than of stock returns. The signs of coefficients are in line with the theoretical findings confirming our model.

Comparing the Model 1 and Model 2, it is clear that our theoretical findings are in line with the empirical data. Increase in real foreign assets is invested in stock returns, so that increases the stock returns. Then, a rise in $\mathrm{V}$ causes appreciation of the domestic currency. On the other hand, as mathematically shown in cointegrating vector estimates, RFLIAB has a higher effect on real exchange rate verifying the discussion on the "debt trap". The capital outflow has a deeper effect on real exchange rate than the inflows.

\subsection{Hong Kong:}

We aim to investigate the global direction of capital flows. The Asian crisis seems to have a contagious effect on the Russian Crisis in 1998. We aim to study the effect of 1997-1998 Financial crises on China.

China is one of the biggest economic players in the world because of both its size and importance for attracting foreign direct investment from various countries. High growth rates and high gross domestic product levels are remarkable. Economist Special Report states that China's share of world GDP is already closer to the rich countries. Indeed, the GDP share of EU and the U.S. shows a declining trend starting from the 1980's and reaches to nearly 20 per cent whereas China and the rest of Asia follows an upward trend reaching to above 15 per cent. Japan has less than 10 per cent of the world GDP. Nevertheless, the population of China, nearly 1.3 billion, clearly affects the GDP per capita. The forecasts for 2007 were still expecting high rates for China. According to the recent forecast of Economic Intelligence Unit), the GDP forecasts of China would be $10 \%$ for 2008 and $9.3 \%$ for 2009 after experiencing $11.5 \%$ in 2007. 
The China region, excluding Hong Kong, attracts a remarkable amount of foreign direct investment which mainly flows from the Asia region, especially Hong Kong. Nevertheless, inward flows to Hong Kong are remarkable compared to the flows to China region. Capital flows to the Financial sector and the FDI to the financial sector has similarities with Turkey ((Gazioglu, 2008), (Loewendahl et al, 2001), (Çulha, 2006))

We focus on Hong Kong, which was under the British control in the $19^{\text {th }}$ century. According to the terms of the Sino-British Joint Declaration on the Question of Hong Kong, signed in 1984, Hong Kong became a Special Administrative Region (SAR) of China promising "a high degree of autonomy" for at least 50 years (Economist Intelligence Unit. Hong Kong has lower growth rates, around 5.5 per cent, than China has. Besides, Hong Kong is one of Asia's leading financial centers and the key international financial center servicing China. As emphasized above, it attracts a huge amount of FDI. Consequently, the structure of economy is the basic motivation to test our claim. Another reason is the rising importance of China and Hong Kong within the China region. It is helpful to analyze the linkages of capital flows for this new player for the sake of future economic policies of China, which will affect the world markets deeper and deeper. After the Asian and Russian financial crises 1997-1998, China became the global financial attraction.

\subsection{Evidence from Hong Kong:}

The nominal effective exchange, foreign assets, foreign liabilities of the banking sector and the consumer price index are gathered from the International Monetary Fund International Financial Statistics for 1994:M1- 2006:M12 time period. All Ordinaries Index series is used as the stock returns index. In figure 5, 6, and 7, the real exchange rate, the real stock market returns and capital inflows, and capital outflows are plotted for 1994:M1- 2006:M12. Focusing on the year 1994, there is a considerable rise in real liabilities, depreciation of the home currency and decrease in the stock returns. After 1995, there is an improvement for all variables. Through out 1993 and 1994, the conflicts between Britain and China in politics over reform for Hong Kong (Burns, 1993) continued. (the introduction of the Special Economic Zones in China). The resolution of this conflict might be the underlying causes of attraction of foreign capital to China. It is noticeable from the empirical analysis that the Asian Crisis in 1998 has positive impact on the Hong Kong. Figure 5 shows that the real exchange rate falls between January 1994-1999, but appreciates between 1997-2002. There was no gap between the liabilities and the assets until 1998, and the gap increased afterwards. This can be interpreted as Asian capital moving out, towards the direction of China.

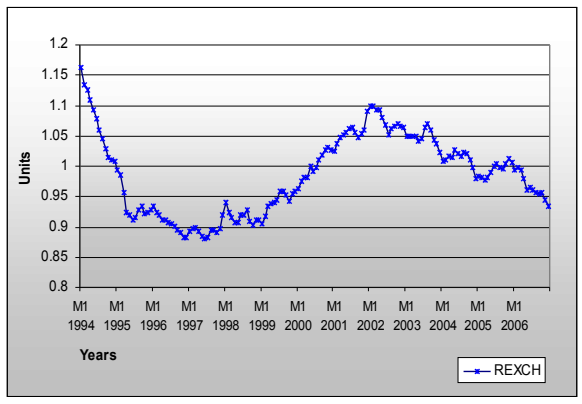

Figure 5 - The Real Effective Exchange Rate for Hong Kong: 1994-2006

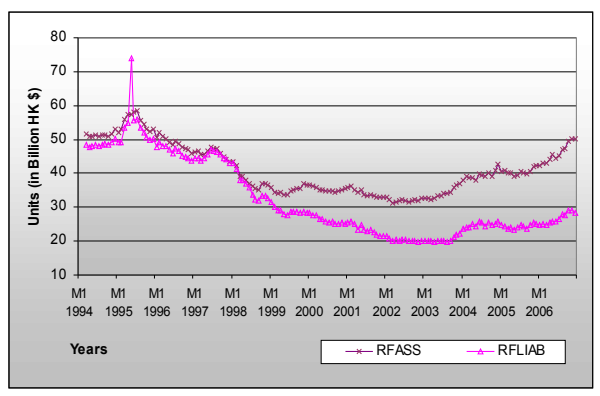

Figure 6 - Real Foreign/Liabilities: for Hong Kong: 1994-2006 


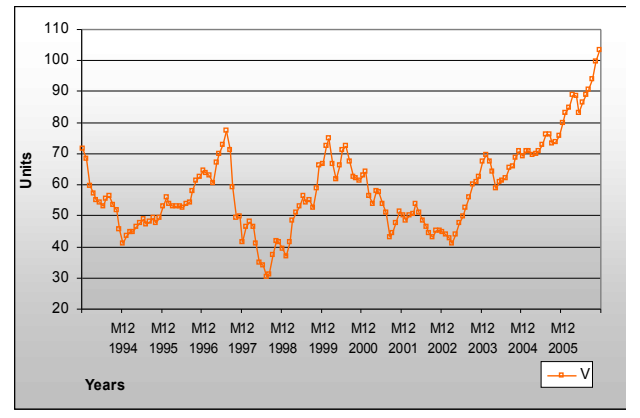

Figure 7 - Real Stock Returns for Hong Kong: 1994-2006
Source: Author's own calculations.

For all variables ADF unit root test is applied and all are integrated of order one. Johansen multivariate technique is applied after including a dummy for 1998. For model 1, a 1\% decrease in stock market returns lead $1.71 \%$ fall (depreciation) of the home currency. Capital inflows into the Banking Sector have very small positive effects. This indicates that capital inflow did not moved into the Banking Sector, has not taken place. We will investigate FDI as an alternative inflow. The sign of DUM $98 \mathrm{HK}$ is positive, indicating that the Hong Kong Dollar still appreciated despite the Asian and Russian crisis. The controversial effect of this dummy variable proves the Asian Crisis improved the economy of Hong Kong contrary to the recession experienced among the Asian countries Gazioglu (2005, 2008). The others (Abeysinghe, 1999) stated that the Asian Crisis transmitted to Hong Kong in very limited manner.

For model 2, capital outflow from banking sector is fairly small. For both Model 1 and 2, we will investigate capital inflow into the stock market and FDI and their reversals.

The basic reason of this finding can be the economic structure of Hong Kong, which greatly differs Russia's. The economy of Hong Kong has ranked the world's freest economy in the Index of Economic Freedom for the 13th consecutive year. Besides, Hong Kong Stock Exchange is one of the largest markets in the world. In 2006 the value of initial public offerings was second highest in the world after London (International Herald Tribune). Accompanied with consecutive high growth rates and developed stock market, the economic performance is comparatively higher for Hong Kong. Consecutively, Hong Kong has not experience the volatility depending on the sudden capital flow shocks as in Turkey or Russia. Rather than the movements of capital, the change in stock returns matter for Hong Kong. Considering the size of the stock market, this finding is not in contrary to our predictions but support the claim that sudden capital flow shocks matter for the countries where there is not enough regulation or institutional framework.

\section{Conclusion:}

This paper considers the relation among real exchange rate, real capital flows and real stock returns for Russia and Hong Kong. The theoretical model of Gazioğlu and McCausland (2002) is empirically tested for Turkey by (Gazioglu, 2003, 2008). The theory predicts that capital inflows via effect on stock returns leads to appreciation, and there is an asymmetry between the effect of inflows and outflows. Our empirical findings from Russia and Hong Kong confirm the theoretical predictions. Comparing the results of Gazioğlu (2008), impact of real liabilities is higher than of real assets meaning that capital outflows has a stronger effect for Turkey and Russia. Furthermore, capital inflow is an important parameter affecting the real exchange rates. Only for Hong Kong the stock returns are more effective than the capital flows because of its exceptional performance of stock markets and overall economy compared to Turkey and Russia. 
Policy implication of this paper relates to capital flows with no restrictions. There is high risk of financial crisis in case of capital reversal. The countries with high foreign investment shares face high risk of financial crisis. Because of the asymmetry, the capital outflows will have deeper effects on exchange rate than capital inflows. These countries are more open to foreign shocks. Some form of capital control possibilities has to be utilized in these countries to be able to smooth the foreign shocks. Further research is needed both to extend the data for other countries and test the theoretical model.

\section{References}

- $\quad$ Abeysinghe, T. ,1999) "Thai Meltdown and Transmission of Recessions within ASEAN4 and NIE4", Paper presented at the conference on International Financial Contagion, How it Spreads, How it Can be Stopped, February 2000, International Monetary Fund, Washington DC

- $\quad$ Eijffinger, S C W; Goderis, Benedickt (2002): "Financial Crises, Monetary Policy and Financial Fragility; A Second-Generation Model of Currency Crises" C.E.P.R. Discussion Papers in its series CEPR Discussion Papers with number 3637

- Burns, J. P. , 1993) "Hong Kong in 1993: The Struggle for Authority Intensifies", Asian Survey, Vol. 34, No. 1, A Survey of Asia in 1993: Part I, pp. 55-63, January.

- Cohen, B., 1998), “The Geography of Money”, Ithaca, NY: Cornell University Press.

- Çulha, A., 2006), "A Structural VAR Analysis of the Determinants of Capital Flows into Turkey", The Central Bank of the Republic of Turkey Research and Monetary Policy Department Working Paper, No.06/05, October.

- Economist (2007), "Reaching For a Renaissance", the Economist Newspaper and the Economist Group, March 292007.

- $\quad$ Eijffinger, S C W; Goderis, Benedickt (2002): "Financial Crises, Monetary Policy and Financial Fragility; A Second-Generation Model of Currency Crises" C.E.P.R. Discussion Papers in its series CEPR Discussion Papers with number 3637

- Gazioğlu, Ş. (2008), "Stock Market Returns in an Emerging Financial Market: Turkish Case Study” Applied Economics, 40(11), pp.1363-1372.

- Gazioğlu, Ş. (2005), "Stock Market, Financial Crisis and Capital Flows in an Emerging Market: Turkish Case Study" in Gazioğlu, S. (eds): Emerging Markets in Financial Crisis: Capital Flow, Saving, Debt and Banking Reform, J-Net Publications, pp. 62-95, 2005.

- Gazioğlu, Ş. and D. McCausland (2002), “A Non-linear Currency Substitution Model of Hysterisis in Debt and Competitiveness", METU Studies in Development, Vol. 29, No. 3-4.

- International Herald Tribune (2006) "Hong Kong surpasses New York in IPOs" (http://www.iht.com/articles/2006/12/25/business/borse.php), published in $25 / 12 / 2005$

- Loewendahl, H. and E. Ertugal-Loewendahl (2001), "Turkey's Performance in Attracting Foreign Direct Investment: Implications of EU Enlargement", ENEPRI Working Paper, No.3, November.

- World Bank (2007), Russian Economic Report 14, the Moscow Office of the World Bank, June. 